\title{
LINII DE SOIA OBȚINUTE ÎN REZULTATUL MUTAGENEZEI INDUSE CU RAZE GAMA
}

\author{
Malii Aliona \\ Institutul de Genetică, Fiziologie și Protecție a Plantelor, Chişinău, Republica Moldova \\ e-mail: malii.aliona@mail.ru
}

\begin{abstract}
Schimbările climatice din ultimii ani reprezintă o provocare prioritară cu care se confruntă întreaga umanitate. Frecvenţa sporită şi intensitatea mai mare a calamităţilor naturale - este deja resimţită și în Republica Moldova. Fenomenele meteorologice extreme, care se manifestă prin ierni calde, primăveri scurte, creșterea și scăderea bruscă a temperaturii, precipitații rare, neregulate și torențiale, inundații, secete frecvente, arșiţe - ca urmare afectează în mod negativ starea morfologică, fiziologică, biochimică și moleculară a culturilor agricole ce duc la diminuarea productivității lor. Din acest motiv, scopul cercetătorilor este de a obține soiuri cu randament ridicat, capabile să realizeze potențialul de productivitate încorporat genetic, cu o calitate ridicată a semințelor în alte condiții decât cele optime, cu rezistență sporită la stres abiotic prin aplicarea metodelor avansate. Soluția acestei probleme depinde în mare măsură de sursa variabilității existente în materialul inițial. În cadrul comunității științifice pe parcursul ultimului deceniu, a crescut interesul către mutageneza indusă, care este utilizată pe scară largă în ameliorarea culturilor agricole pentru a obține materialul iniţial valoros. Îmbunătățirea culturilor alimentare din lume se bazează în principal pe mutație. Mutageneza indusă la soia, este un supliment dovedit și un înlocuitor eficient al reproducerii convenţionale pentru a conferi o îmbunătăţire specifică într-o varietate fără a afecta în mod semnificativ fenotipul său acceptabil. În studiile noastre, s-a utilizat mutageneza indusă cu raze gama, urmată de selectarea individuală a formelor valoroase dorite. Materialul cercetat prezintă linii obținute în generația $M_{6}$. Pentru analiza comparativă au fost folosite două soiuri - martor de soia (s. Zodiac și s. Alina), omologate în R. Moldova. Boabele uscate au fost iradiate cu raze gama, cu doze de 100, 150, 200 și 250 Gy, și semănate în câmpul experimental conform metodelor generale acceptate pentru această cultură. Studiile au fost realizate în perioada anilor 2013-2015. Din descendența $\mathrm{M}_{3}-\mathrm{M}_{6}$, individual au fost selectate linii, care prin randament total, diferă semnificativ de plantele martor. Pe parcursul celor trei ani de cercetare (2013-2015), în condiții de câmp și laborator, aceste linii au demonstrat o mare variație a productivității per plantă și a masei 1000 boabe. Rezultatele obținute la productivitatea per plantă au arătat că unele linii, în funcție de condițiile anului, au depășit valorile martorului, în timp ce altele erau inferioare. Rezultate similare au fost obținute și la indicii masei 1000 boabe. Aceste diferențe sunt mai pronunțate în anii 2014-2015, care s-au caracterizat prin secetă severă.
\end{abstract}

Rezultatele cercetărilor au arătat, că utilizarea mutagenezei induse cu raze gama la soia a făcut posibilă obținerea de noi linii caracterizate prin rate mai mari, atât în productivitate, cât și în calitatea boabelor. Liniile selectate vor fi incluse în programele de lucru pentru studii de reproducere și studii genetice ulterioare. Pe baza lor se vor obține noi soiuri cu productivitate înaltă, rezistente la boli, vătămători, secetă şi la diverși factori climatici care prezintă o problema de risc major pentru agricultura Republicii Moldova. 